\title{
EARLY AND RECENT DEVELOPMENT OF RECONSTRUCTIVE MICROSURGERY SUBSPECIALTY IN DR. CIPTO MANGUNKUSUMO NATIONAL HOSPITAL, UNIVERSITAS INDONESIA (1983-2020)
}

\author{
Mohamad Rachadian Ramadan ${ }^{1}$, Nadhira Anindita Ralena ${ }^{2}$, Sara Ester Triatmoko ${ }^{1}$, Parintosa Atmodiwirjo
}

1. Reconstructive Microsurgery Section, Division of Plastic Surgery, Faculty of Medicine Universitas Indonesia, dr. Cipto Mangunkusumo National Hospital. Jakarta, Indonesia.

2. Faculty of Medicine, Universitas Indonesia. Jakarta, Indonesia

\begin{abstract}
Summary: Plastic surgery in Indonesia was pioneered and developed by Moenadjat Wiratmadja, MD., in 1958. This specialty developed and improved over time with more specific subspecialties to facilitate the advancement of the science of plastic surgery, including the reconstructive microsurgery subspecialty. The reconstructive microsurgery service in the plastic surgery division dr. Ciptomangunkusumo National Hospital (RSCM), Jakarta, Indonesia was first initiated by Sidik Setiamiharja, MD., an amid self-learner reading from the textbooks. Late 1985, following the success of conducting the first basic microsurgery course in Jakarta, the plastic surgery team in RSCM which consisted of Sidik Setiamihardja, MD, Chaula L. Sukasah, MD and Gentur Sudjatmiko, M.D. pioneered many of the first microsurgery cases, including the first major upper-limb replantation, first penile replantation, first free flap and the first vascularized bone flap . Overtime, the reconstructive microsurgery subspecialty in RSCM-FKUI has been growing significantly. In 2019, the number of free flap cases at RSCM reached the highest number in Indonesia with 90 free flap cases with $94 \%$ success rate.

Keywords: History, Plastic Surgery, Reconstructive Microsurgery, Indonesia

Ringkasan: Bedah plastik di Indonesia dirintis dan dikembangkan oleh dr. Moenadjat Wiratmadja pada tahun 1958. Bagian spesialistik ini mengalami banyak perkembangan dan peningkatan seiring waktu dengan subspesialisasi yang lebih spesifik untuk memfasilitasi kemajuan ilmu bedah plastik, termasuk subspesialisasi bedah mikro rekonstruktif. Layanan bedah mikro rekonstruktif di divisi bedah plastik Rumah Sakit Umum Pusat Nasional Dr. Cipto Mangunkusumo (RSCM), Jakarta, Indonesia pertama kali diinisiasi oleh dr. Sidik Setiamiharja, dengan cara belajar mandiri dari buku teks. Pada akhir 1985, setelah keberhasilan menyelenggarakan kursus bedah mikro dasar pertama di Jakarta, tim bedah plastik di RSCM yang terdiri dari dr. Sidik Setiamihardja, dr. Chaula L. Sukasah dan dr. Gentur Sudjatmiko mepelopori banyak kasus bedah mikro pertama, termasuk replantasi tungkai atas mayor pertama, replantasi penis pertama dan free flap pertama. Seiring berjalannya waktu, subspesialisasi bedah mikro rekonstruktif di RSCM-FKUI telah berkembang secara signifikan. Pada tahun 2019, jumlah kasus free flap di RSCM mencapai jumlah tertinggi di Indonesia dengan 90 kasus free flap dengan tingkat keberhasilan $94 \%$.
\end{abstract}

Kata Kunci: Sejarah, Bedah Plastik, Bedah Mikro, Indonesia

Conflicts of Interest Statement:

The author(s) listed in this manuscript declare the absence of any conflict of interest on the subject matter or materials discussed.

History of Plastic Surgery in Dr. Cipto Mangunkusumo Hospital

Plastic surgery division in dr. Cipto Mangunkusumo Hospital, Jakarta, Indonesia was pioneered and developed by Moenadjat
Wiratmadja MD., a general surgeon graduated from the Faculty of Medicine Universitas Indonesia (FKUI) in 1958. Soon after graduating He pursued his plastic surgery training at Washington University School of Medicine, Barnes Jewish Hospital, St. Louis, USA for a year. 
Moenadjat Wiratmadja MD. visited the division of plastic surgery Washington University when it was chaired by James Barrett Brown, MD. which was the sole successor of "Father of the American Board of Plastic Surgery", Vilray P. Blair MD. ${ }^{1,2}$ Moenadjat Wiratmadja's training was directly under the virtue of the chairman, who is a pioneer in plastic surgery education and has trained more than 100 plastic surgeons, many of who them has become leaders of their services, in world bestknown plastic surgery center. ${ }^{1}$ Some of the notable James Barrett Brown's student was Ralph Millard MD. who has pioneered cleft repair and Joseph Murray MD., the first plastic surgeon to perform kidney transplantation. $1,2,3$

Upon the completion of his plastic surgery training in 1959, Moenadjat Wiratmadja MD. returned to Indonesia, and started to dedicate his newly-found knowledge to patients and pioneered the first plastic surgery education system for medical students and surgery trainee in FKUI and dr. Cipto Mangunkusumo National Hospital (RSCM). By de facto, the surgical trainee who was accepted under his apprenticeship was general surgery graduates from the FKUI. The staff from the general surgery department and the medical faculties were considered a priority to be accepted as the apprentices. Two years of training in plastic surgery were required. The first surgical trainee He took as apprentice was Bisono, MD., a general surgeon who completed his plastic surgery study in 1971, then Sidik Setiamihardja, MD., a general surgeon who completed His plastic surgery education in 1974. After graduating, the two immediately became staff members of the plastic surgery division of RSCM-FKUI. Moenadjat Wiratmadja, MD. achieved the title as Professor of surgery in 1979. When Prof. Moenadjat passed away, the head of plastic surgery division RSCM position was replaced by Sidik Setiamihardja, MD. ${ }^{4-6}$

\section{History of Plastic Surgery Training Program in Universitas Indonesia}

In 1990, FKUI was established by the Minister of Higher Education in Indonesia as the first training center of plastic surgery in the countries, along with that, the syllabus and curriculum of plastic surgery education began to be implemented in FKUI. Students who are eligible to enroll are general practitioners who have completed the undergraduates mandatory work. The duration of the whole plastic surgery training was nine semesters..$^{5-7}$ General surgery graduates who wish to join the plastic surgery training programs can still be accepted as students if they have been recommended by teaching hospitals or universities. As the higher education regulations in Indonesia developed, the model of plastic surgery specialist training was transformed to an official standalone training program outside the general surgery training program. Students are not required to graduate from a general surgery training to apply for plastic surgery specialist education. The plastic surgery training program FKUI is officially established in 1989 with the decree No. 107/DIKTI/Kep/1989 on November $1^{\text {th }}, 1989$ by the General Director of the Higher Education, Sukadji Ranuwihardjo. This program is the first plastic surgery training program in Indonesia. Based on the decree, then on January $1^{\text {st }}, 1990$ this training program began organizing integrated education and learning activities combined with plastic surgery medical services for patients. The first program director was Bisono, MD. as de facto position following Moenadjat Wiratmadja, MD. and after de jure recognition until March 2003. Since April 2003, the program director position has been replaced by Gentur Sudjatmiko, MD until 2012 which was later replaced by Parintosa Atmodiwirjo, MD until 2019.4-11 Currently, there are five reconstructive and aesthetic plastic surgery training programs in Indonesia. All of these university based education programs are organized by 5 universities in Indonesia, including Universitas Indonesia, Airlangga University, Padjadjaran University, Udayana University, and Syiah Kuala University. ${ }^{4-12}$

\section{Early Development of Reconstructive Microsurgery Subspecialty (1983)}

The reconstructive microsurgery service in plastic surgery division RSCM was pioneered by Sidik Setiamiharja, MD. in 1983. Being an amid self-taught from the textbooks, $\mathrm{He}$ began practicing anastomosis femoral artery in a rat living model using table electronic microscopes donated from the government of Jakarta city. ${ }^{10}$ Chaula L. Sukasah, MD. who was just graduated in 1983 and recruited as the staff of plastic surgery division RSCM also joined the microsurgery exercise. She developed Her 
interest to microsurgery during the fellowship at Showa University, Japan in 1981. There She attended the basic microsurgery training in animal lab.4,13,14

In 1985, the first basic microsurgery training was held in Malang, East Java, the event was conducted by the Orthopaedic team from Airlangga University such as Djoko Roeshadi, MD. and Satrio, MD. in cooperation with Dutchbased non-profit organization. The course director was a Dutch plastic surgeon: Robinson, MD. ${ }^{13,14}$ Djoko Roeshadi, MD. a hand orthopedic surgeon is well known to perform the first successful finger replantation in Indonesia in 1981. ${ }^{12,14}$ The basic microsurgery training was supported with 40 electronic microscopes brought directly from Netherland by the Foundation and was held for 1 week. 13,14 One of the modules delivered in this training were endto-end anastomosis of the carotid and femoral artery of the living rats. Two delegates from plastic surgery division RSCM joined in this program, Chaula L. Sukasah, MD. who was already staff of plastic surgery division RSCM and Gentur Sudjatmiko, MD. who was still the chief plastic surgery resident. ${ }^{13,14}$

After returning from the course in Malang, there were a surge of interests in microsurgery specialties within the plastic surgery division. Gentur Sudjatmiko, MD. was appointed by the head of the plastic surgery division RSCM to arrange the first basic microsurgery course in RSCM. ${ }^{13}$
Robinson MD. and the team were asked to bring the course and all 40 electronic microscope tables to the RSCM. This training invites other departments pertinent to microsurgery skill, such as orthopedic, ophthalmology, ENT, neurosurgery, and more. ${ }^{13}$

In late 1985, following the success of conducting the first basic microsurgery course in Jakarta, the plastic surgery team in RSCM which consisted of Sidik Setiamihardja, MD, Chaula L. Sukasah, MD and Gentur Sudjatmiko, MD. pioneered many of the first microsurgery cases in RSCM, including the first major upper limb replantation, the first penile replantation, the first free flap and the first vascularized bone flap. ${ }^{13,14}$

The first successful major upper limb replantation case recorded in RSCM, was carried out by the plastic surgery team led by Chaula L. Sukasah, MD in late 1985.14 A 20-year-old man came to the emergency department RSCM bringing his left-hand amputee, which was slashed by the opponent's blade during a street fight (Figures 1). Chaula L. Sukasah, MD. immediately came to the emergency department, and start preparing for the replantation using only surgical loupes. Intraoperatively traumatic amputation at palm to wrist level was observed, all amputated segments were replanted, including bones, tendons, veins, nerve, and arteries (Figures 2). This case was done by the plastic surgery team only, including the bone
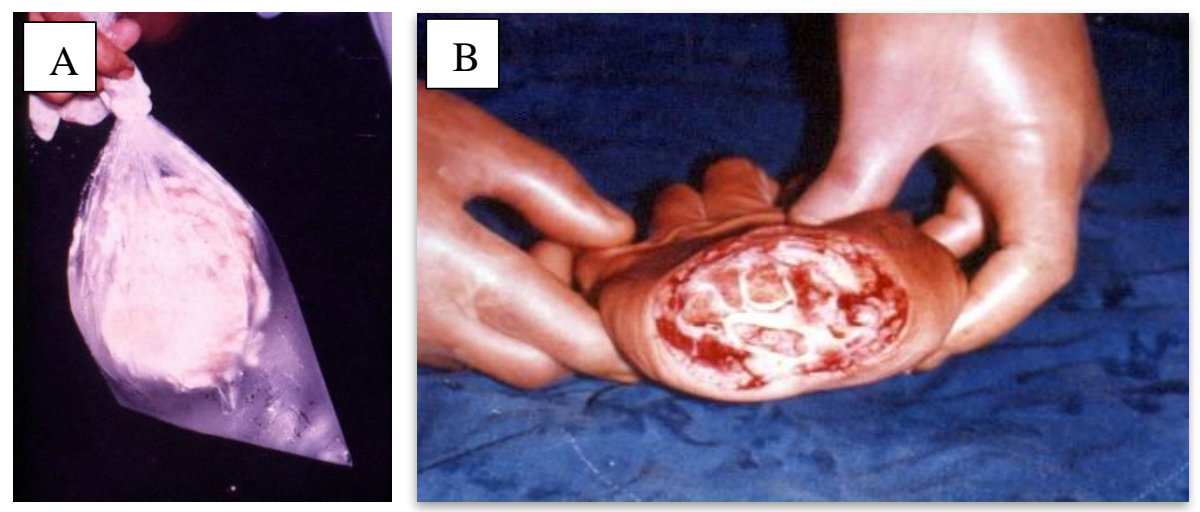

Figures 1. (A) Amputee brought inside plastic bags filled with ice. (B) Transverse view of the amputee at wrist level depicting clean cut. Images obtained with permission from Sukasah C.L. The beginning of microsurgery in the division of plastic surgery FKUI-RSCM. 2014. Presented at Indonesian Reconstructive Microsurgery Course and Symposium, Semarang 2014.14 

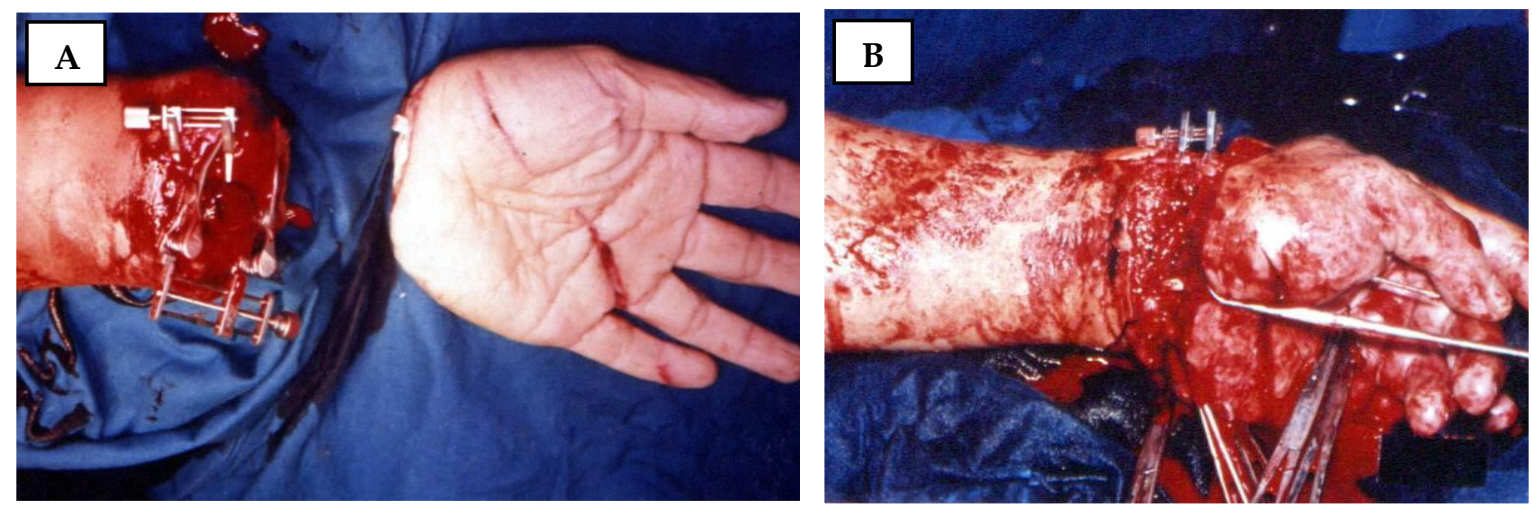

Figures 2. (A) Intraoperative pictures before replantation. (B) After replantation of bones, tendons, nerves, arteries, and veins. Images obtained with permission from Sukasah C.L. The beginning of microsurgery in the division of plastic surgery FKUI-RSCM. 2014. Presented at Indonesian Reconstructive Microsurgery Course and Symposium, Semarang 2014. ${ }^{14}$
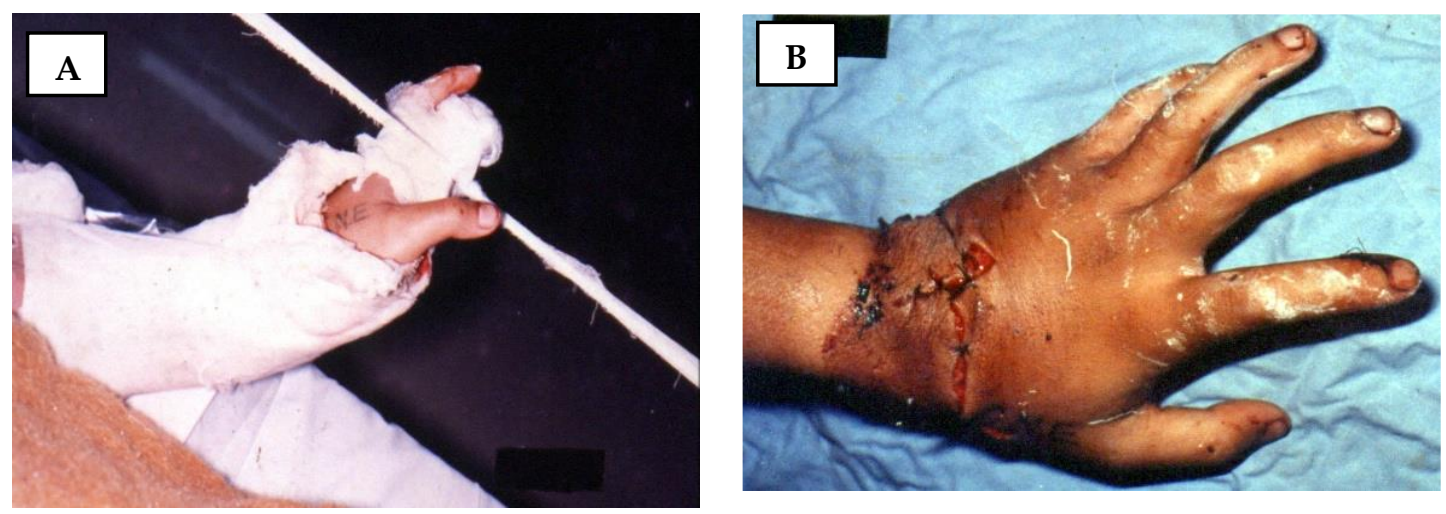

Figures 3. (Left) Post-operative pictures, hand positioned with traditional slab (Right) Follow-up images revealing vital hand. Images obtained with permission from Sukasah C.L. The beginning of microsurgery in the division of plastic surgery FKUI-RSCM. 2014. Presented at Indonesian Reconstructive Microsurgery Course and Symposium, Semarang 2014.14

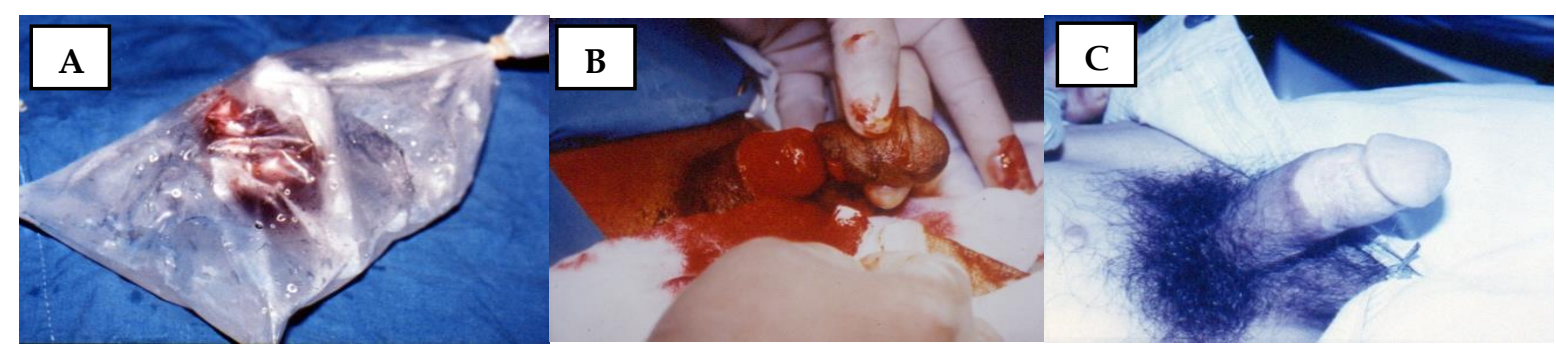

Figures 4. (A) Penile amputee of self-inflicted amputation in a patient with a psychiatric disorder (B) Intraoperative pictures of penile replantation, all structures including, cavernous corpus, urethra, arteries, vessel, and vein. (C) The amputee was vital with good erectile function on follow-up. Images obtained with permission from Sukasah C.L. The beginning of microsurgery in the division of plastic surgery FKUI-RSCM. 2014. Presented at Indonesian Reconstructive Microsurgery Course and Symposium, Semarang 2014.14

internal fixations. On the follow-up the replanted amputee was vital, making this the first case of successful major upper-limb replantation in RSCM, and arguably in Indonesia (Figures 3). ${ }^{14}$
Chaula L. Sukasah's dedication and perseverance on attending all traumatic amputation cases in emergency settings leads to the increased attention of the plastic surgery division RSCM by 

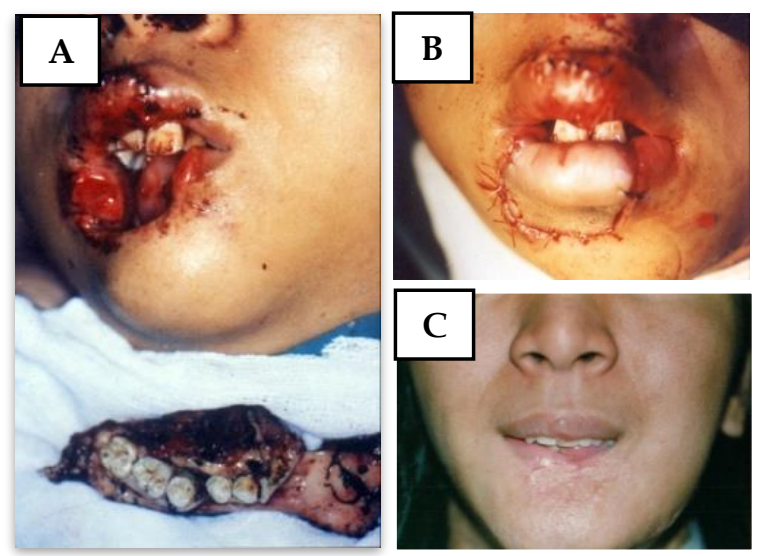

Figures 5. (A) Lower-lip amputation in the 12-year-old child including segmental mandible due to a motorvehicle accident $(B)$ Intraoperative pictures of lip replantation, all structures including, bones, muscle, nerves, arteries, and veins were replanted (C) 8 year follow up with good aesthetic and functional outcomes. Images obtained with permission from Sukasah C.L. The beginning of microsurgery in the division of plastic surgery FKUI-RSCM. 2014. Presented at Indonesian Reconstructive Microsurgery Course and Symposium, Semarang 2014. ${ }^{14}$
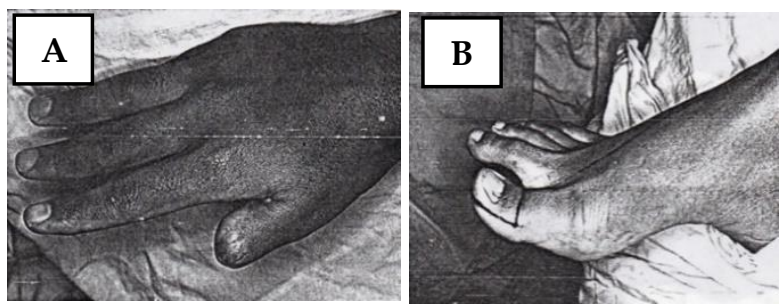
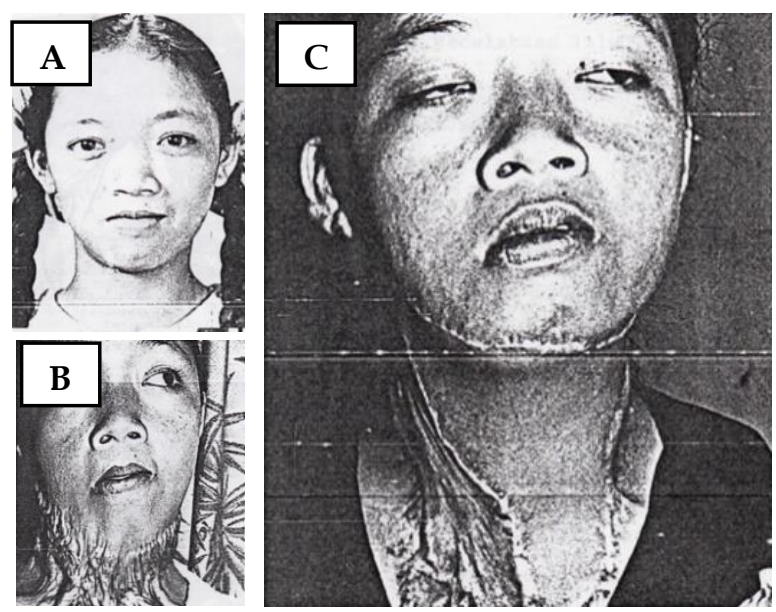

Figures 6. (A) Before burn accident. (B) 6 years after burns accidents, (C) One-year follow-up post reconstruction with extended scapular free flap and full-thickness skin graft with good aesthetic and functional outcomes. Images obtained with permission from Sudjatmiko, G. Bedah Mikro di Bidang Bedah Plastik (Tulisan Akhir).1987. Program Pendidikan Ahli Bedah Plastik, Fakultas Kedokteran Universitas Indonesia. ${ }^{13}$

Figures 7. (A) Amputated right thumb. (B) Donor site flap design from the great toe; (C) Bone grafts in place on the tip of the thumbs. (D) 10 days postoperative after toe transfer. Images obtained with permission from Sudjatmiko, G. Bedah Mikro di Bidang Bedah Plastik (Tulisan Akhir).1987. Program Pendidikan Ahli Bedah Plastik, Fakultas Kedokteran Universitas Indonesia. 13

public and media. ${ }^{14}$ More complex traumatic amputation cases were successfully replanted including the first penile replantation in 1990 (Figures 4), and lower lip amputation in 1990 (Figures 5) all done by the plastic surgery team only..$^{14}$

Also in late 1985, the plastic surgery team consisted of Sidik Setiamiharja, MD. and Gentur Sudjatmiko, MD. recorded the first successful microsurgical free flap reconstruction performed in RSCM, the first in Indonesia. ${ }^{13}$ This first free flap case was done to reconstruct a neck contractures due to burns using extended scapular fasciocutaneous free flaps using recipient vessels from neck. The patient was followed up for 1 year with good functional and aesthetic outcomes (Figures 6). Several months after the first free flap performed, the first successful toe-to-thumb transfer in RSCM using Morisson's technique was performed to the same patient. (Figures 7). ${ }^{13}$

Around the year of 1986, Sidik Setiamihardja, MD. awarded a traveling scholarship and went for his observership in Department of Plastic Surgery, Stanford University, California, USA. There He observed a mandible reconstruction surgeries using the vascularized iliac bone-free flap to cover a defect on the mandible. Coming back to Indonesia, Sidik Setiamiharja, MD and Gentur Sudjatmiko, MD 

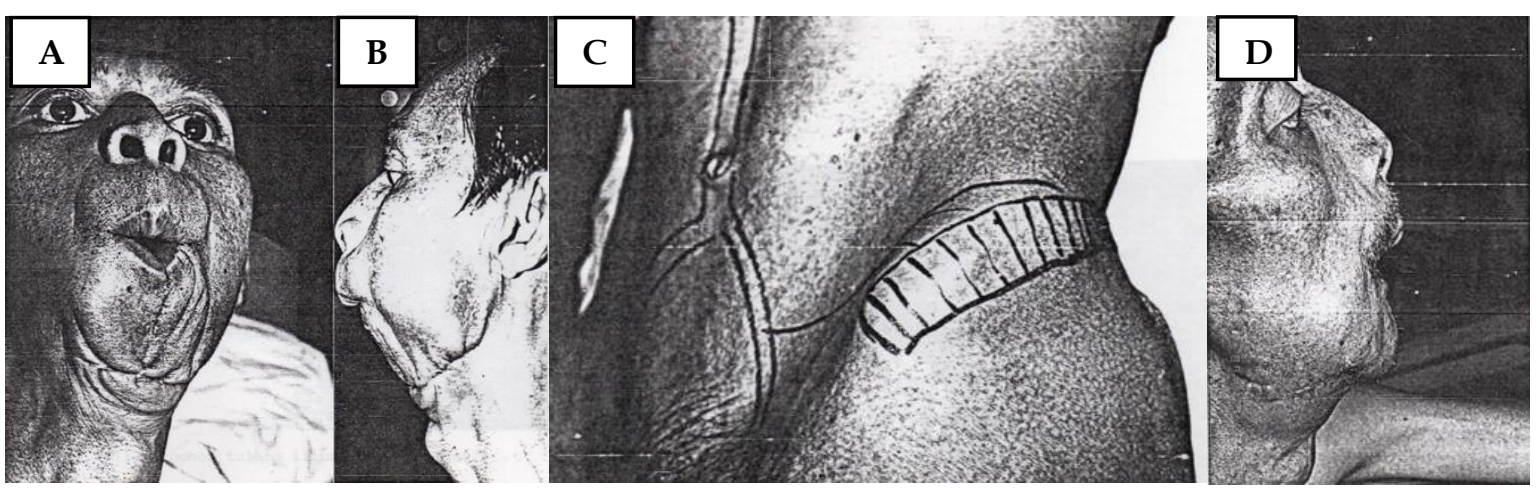

Figures 8. (A, B) Symphiseal mandible bone defects following resection of adantimoma done by an oncologic surgeon. (C) Vascularised iliac bone flap design. (D) Post-operative images after reconstruction of symphyseal bone defects using the vascularized iliac bone flap. Images obtained with permission from Sudjatmiko, G. Bedah Mikro di Bidang Bedah Plastik (Tulisan Akhir).1987. Program Pendidikan Ahli Bedah Plastik, Fakultas Kedokteran Universitas Indonesia. ${ }^{13}$

who was still the chief plastic surgery resident together conduct the first vascularized bone transfer in RSCM for the reconstruction of symphyseal mandible bone defects due to Adantimoma resection done by Oncologic Surgeon. The bone free flap was transferred to the mandible and anastomosed to superior thyroid arteries and external jugular vein recipients using microsurgery techniques. On the follow-up, the flap was successful and uneventful (Figures 8). Gentur Sudjatmiko, MD. documented all of his microsurgical free flap reconstruction performed in plastic surgery division RSCM in his final theses in 1987, before graduating as plastic surgeon. ${ }^{13}$

The microsurgery services in RSCM was then carried on with the contribution of future staff who pursued and dedicate their careers in this field, many of whom underwent fellowships training in with giants of microsurgery abroad. These microsurgery staffs consisted of Gentur Sudjatmiko, MD. (trained with Wayne Morisson MD., St . Vincent Hospital, Melbourne, Australia), Gwendy Aniko, MD. (trained with Harry Buncke MD., at Buncke Clinic, San Francisco USA), Theddeus O.H.P., MD. (trained with Harry Buncke MD., at Buncke Clinic, San Fransisco USA and trained at MD Anderson Cancer Center, Houston, USA), Parintosa Atmodiwirjo, MD. (trained with Chih Hung Lin, MD. at Chang Gung Memorial Hospital, Taiwan), Mohamad Rachadian Ramadan (trained with S.R. Sabapathy MD. at Ganga Hospital, India, with Fu Chan Wei, MD. at Chang Gung Memorial Hospital, Taiwan and
Eric Santamaria, MD. at Gea Gonzalez Hospital, Mexico), Sara Ester Triatmoko, MD. (trained with Ong Yee Siang, MD. at Singapore General Hospital). $4,6,8,15,16$

\section{Recent Development of Reconstructive Microsurgery Subspecialty (2020)}

Many graduates from plastic surgery training program FKUI also dedicate their careers for this microsurgery subspecialties and successfully developed microsurgery services in their institution. Some of the most active FKUI graduates who consistently performed microsurgery across Indonesia were: Nyoman P. Riassa, MD. (Sanglah Hospital, Bali), Najatullah, MD. (dr. Kariadi Hospital, Semarang), Budiman, MD. (Gatot Seobroto Army Hospital, Jakarta), Dewi Mukkarramah, MD. (Dharmais Cancer Hospital, Jakarta), and many more. ${ }^{16}$

In 2014, plastic surgery division RSCM applied the sub-majoring system among its staffs to facilitate the advancement of plastic surgery, several examples of sub-majoring developed were burns, craniomaxillofacial, hand surgery, reconstructive microsurgery, external genital, and wound-oncoplasty. $4,6,7,8,11$

From 2014 until present reconstructive microsurgery section of plastic surgery division RSCM was led by Parintosa Atmodiwirjo, MD. He was the only staff of the section and performed all free flaps accompanied by plastic surgery residents only. Within this period, stronger collaboration with other departments in 


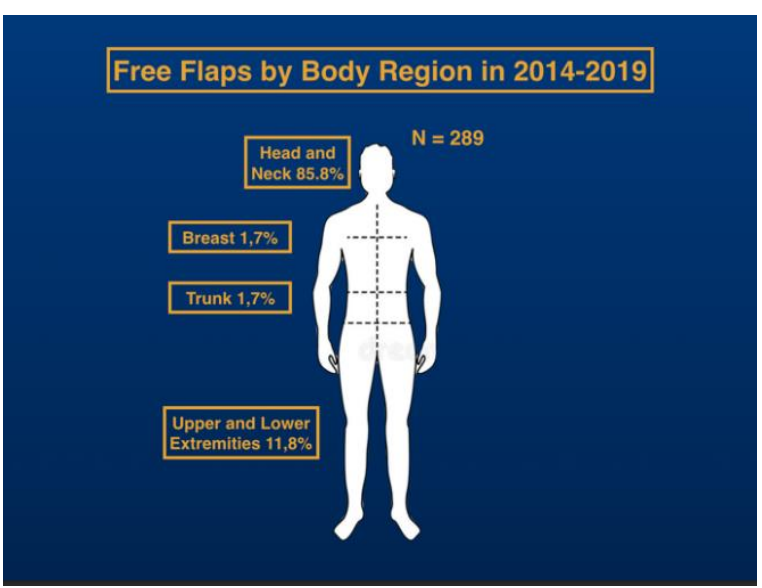

Figure 9. Free flaps by body region in 2014-2019 in reconstructive microsurgery section RSCM. ${ }^{16}$

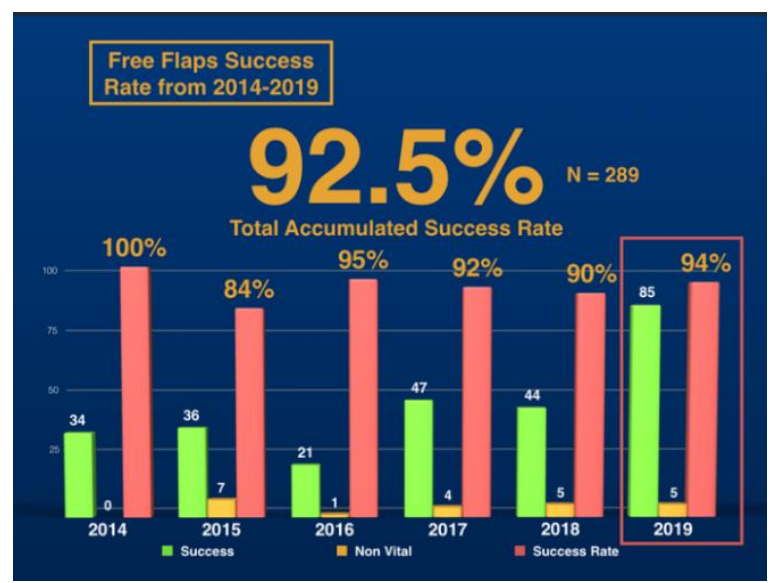

Figure 10. Free flaps success rate from 2014-2019 in reconstructive microsurgery section RSCM. ${ }^{16}$

the hospital such as oncologic surgery, ENT and oral surgery have been excelled, and resulted in $85,8 \%$ of total free flap cases that were head and neck reconstruction (Figure 9), mostly due to cancer resection, trauma or infection referred from them. The good reputation of reconstructive microsurgery section led by Parintosa Atmodiwirjo, MD., comes from total accumulated $92,5 \%$ success rate from the last 6 years (Figure 10), has earned the trusts and confident from other departments in the hospital that sends more free flaps candidates over years. 16

In 2019 with the addition of two young staff in reconstructive microsurgery section, Sara Ester Triatmoko, MD. and Mohamad Rachadian Ramadan, MD. the number of free flaps continues to increase to almost double, to 90 cases, compared to 2018 which accounted to 47 cases
(Figure 11). The number of microsurgery cases at the RSCM in 2019 reached the highest number in Indonesia compared to other advanced microsurgery centres such as Dharmais Cancer Hospital, Dr. Soetomo Hospital, Dr. Kariadi Hospital, and Sanglah Hospital. In 2019 the success rate was increased by $4 \%$ to $94 \%$, which already reach the world minimum standard for an advanced microsurgery centre (>94\%). ${ }^{16}$

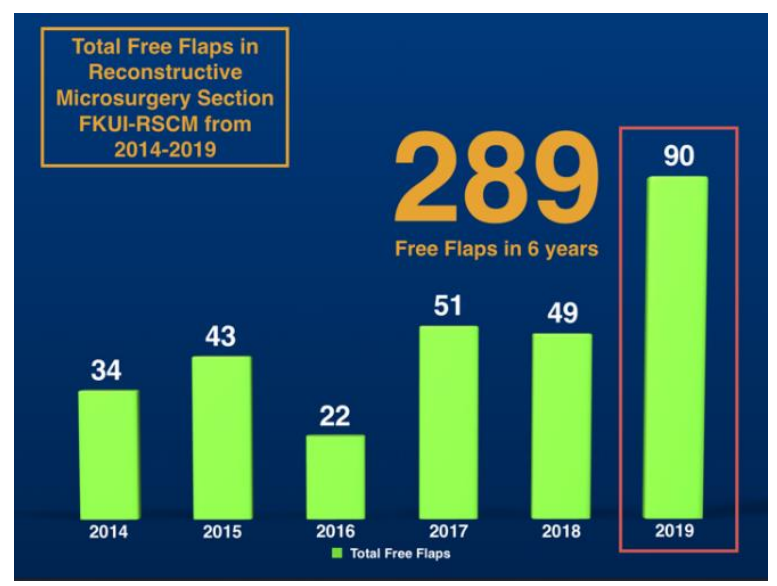

Figure 11. Total free flaps case in reconstructive microsurgery section FKUI-RSCM. ${ }^{16}$

From the last 6 years, there were 248 head and neck free flap cases recorded, comprising of $85,8 \%$ of total of free flaps performed. ${ }^{16}$ Reconstructing head and neck defects following cancer resection, trauma or infection requires not only good functional outcome but also aesthetic outcomes to ensure the best quality of life for patients and their psychosocial acceptances after surgeries. Thus, the concept of reconstructing defect using free flaps in the reconstructive microsurgery section RSCM has evolved from only "covering hole or defects" using big blob of flap, to "replacing like with like tissue" by applying three-dimensional refinement and precise tailoring for each patients (Figure 12 and Figure 13). In 2019 there are total 186 surgeries in reconstructive microsurgery section, 90 of them are free flaps, and the other 96 procedures were secondary or refinement procedures of previous free flaps surgeries (Figure 14), that may include thinning of the flaps, three-dimensional shaping, frameworks reconstruction and aesthetic scar refinements. ${ }^{16}$ 


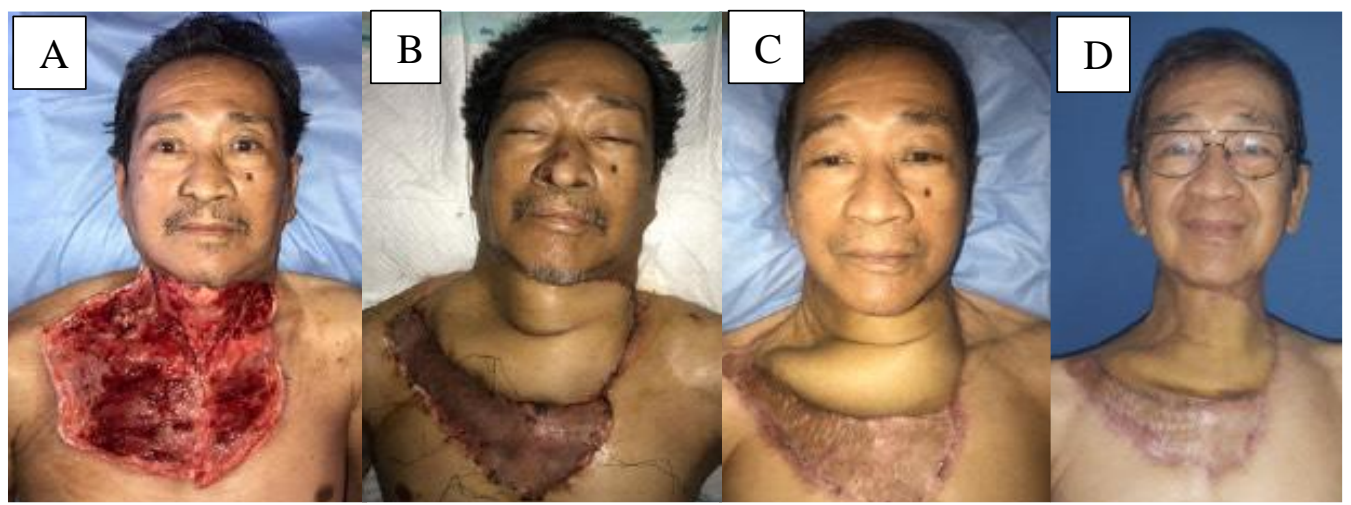

Figure 12. (A) Wide defects on neck to sternal area following debridement of infections. (B) 7 days postoperative result of ALT free flap to cover the defect combined with STSG. (C) 3 months follow-up (D) Post flap refinement procedures using liposuction. Images taken with permission from Atmodiwirjo P, Aulia I. How to harvest ALT free flap: step-by-step. 2020. LSBP Press: Jakarta.

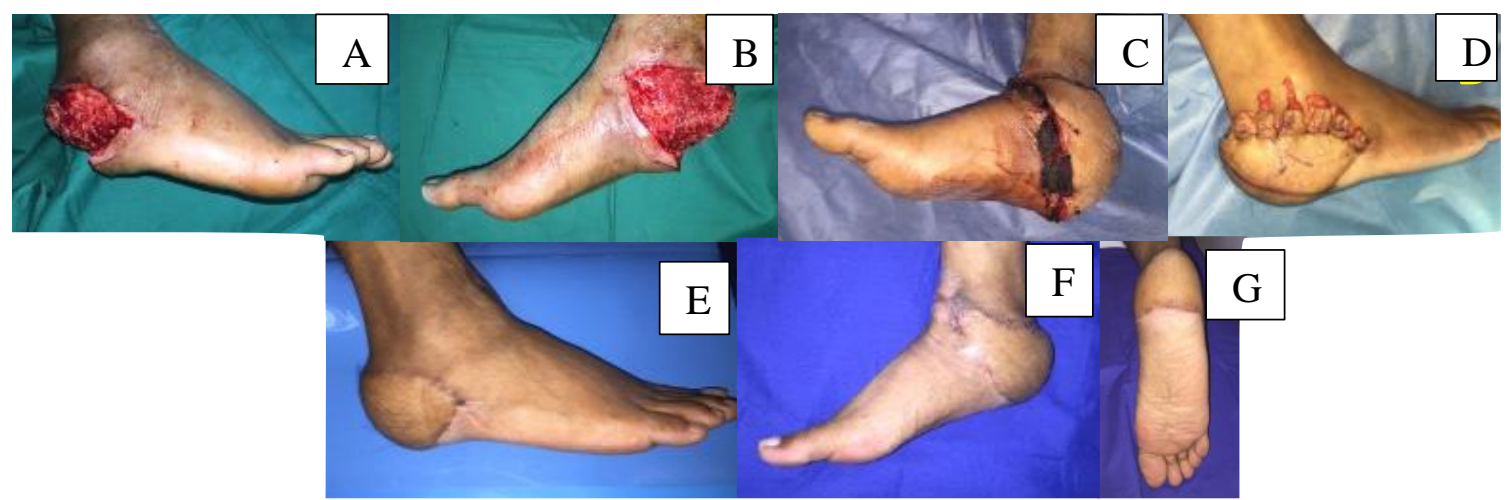

Figure 13. (A) Defect of the calcaneal areas following trauma from fibular side (B) Defects from tibial side (C) Defect covered by ALT free flaps (D) First refinement procedures: liposuction and excessive skin tailoring. (E, F, G) The final results after refinement procedure which improved the patient's foot contour for shoe fitting and his gait balance. Images taken with permission from Atmodiwirjo P, Aulia I. How to harvest ALT free flap: step-by-step. 2020. LSBP Press: Jakarta.

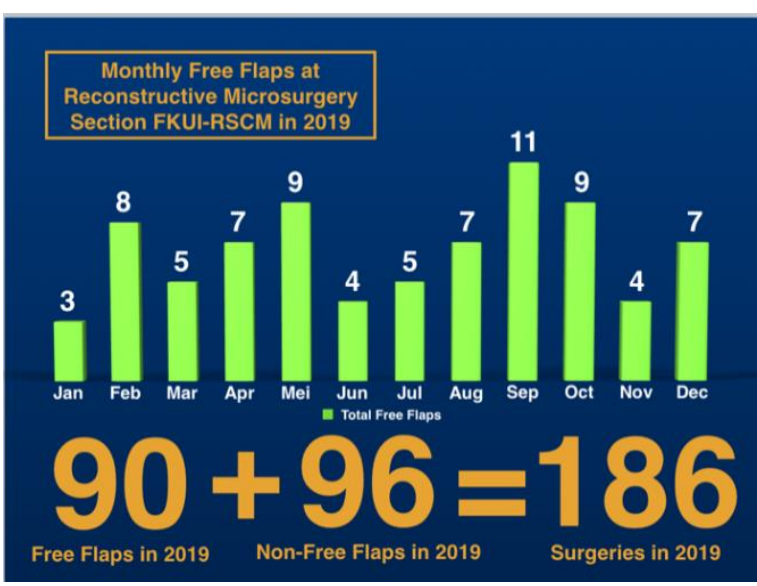

Figure 14. Total free flaps and non-free flap cases in reconstructive microsurgery section FKUI-RSCM in 2019. 16

\section{SUMMARY}

In summary, the development of reconstructive microsurgery subspecialty in RSCM-FKUI from 1983 which pioneered by Sidik Setiamihardja, MD, Chaula L. Sukasah, MD and Gentur Sudjatmiko, M.D. with several novel procedures in Indonesia, such as the first penile replantation, first major upper-limb replantation, ,first free flap and first vascularised bone flap. At presents many graduates from FKUI dedicate their careers and perform reconstructive microsurgery services across Indonesia. The early microsurgeon in RSCM-FKUI has inspired the younger generations to keep thriving and developing themselves in this ever-evolving subspecialties. 


\section{ACKNOWLEDGEMENT}

Thank you to our teachers Sidik Setiamihardja, MD, Chaula L. Sukasah, MD and Gentur Sudjatmiko, M.D. for their tremendous support in gathering information on microsurgery subspecialty history in Dr. Cipto Mangunkusumo Hospital.

\section{Correspondence regarding this article should be} addressed to:

Mohamad Rachadian Ramadan, MD.

Reconstructive Microsurgery Section, Division of P\{lastic Surgery, Dr. Cipto Mangunkusumo National Hospital, Universitas Indonesia. Jakarta 12310, Indonesia

E-Mail: mohamad.rachadian@ui.ac.id

\section{REFERENCES}

1. Stelnicki EJ, Young VL, Francel T, Randall P. Vilray P. Blair, his surgical descendants, and their roles in plastic surgical development. Plast Reconstr Surg. 1999 Jun;103(7):19902009.

2. Hallock GG, The Plastic Surgeon of the 20th century. Plast Reconstr Surg. 2001 Apr; 107(4):1014-1024

3. Indonesian Reconstruction and Aesthetic Plastic Surgery Specialist Association. Doctors. Available from: http://www.perapisurgeon.org [Accessed 2th December 2019].

4. Panigoro SS, Lalisang T, Moenadjat Y. Melintasi 100 Tahun Ilmu Bedah Indonesia. 2019. Jakarta: FKUI Publishing.

5. Sukasah CL. From cutting to cooking: the quest for Indonesia first female surgeon. Journal of Plastic Reconstruction. 2012; 1 (3): 357-358.

6. Atmodiwirjo P, Handayani S, Kreshanti P, Aulia I. Self Evaluation of LAM-PTKes Accreditation. 2018. FKUI Reconstructive and Aesthetic Plastic Surgery Study Program. Report.

7. Indonesian Association of Plastic Surgeons. History of plastic surgery in Indonesia. 2019. Available from: http://www.perapisurgeon.org [Accessed 19th November 2019]

8. Atmodiwirjo P. The study program of reconstructive and aesthetic plastic surgery FKUI-RSCM. 2018. [Presentation] University of Indonesia. 07 February 2018.
9. Specialist 1 Reconstructive and Aesthetic Plastic Surgery Faculty of Medicine, Airlangga University. 2019. Available at: http://spesialis1.bpre.fk.unair.ac.id/alumni [Accessed 2th December 2019].

10. Faculty of Medicine, Udayana University. Reconstructive and aesthetic plastic surgery study program. 2019. [online] Available https:/ / fk.unud.ac.id/ ?page_id=363

[Accessed 2th December 2019].

11. Atmodiwirjo P, Handayani S. Handbook of the professional doctor's professional education study program-1 reconstructive and aesthetic plastic surgery. 2016. FKUI Reconstructive and Aesthetic Plastic Surgery Study Program Guideline.

12. Faculty of Medicine, University of Airlangga. Program Studi PPDS 1 orthopaedi. (2016). History - Program Studi PPDS 1 orthopaedi. [online] Available at: http://spesialis1.orthopaedi.fk.unair.ac.id/e n/sejarah [Accessed 24 Feb. 2020].

13. Sudjatmiko, G. Bedah Mikro di Bidang Bedah Plastik (Tulisan Akhir).1987. Program Pendidikan Ahli Bedah Plastik, Fakultas Kedokteran Universitas Indonesia.

14. Sukasah C. L. The Beginning of Microsurgery in The Division of Plastic Surgery FKUIRSCM. 2014. Presented at Indonesian Reconstructive Microsurgery Course and Symposium, Semarang 2014.

15. Indonesian College of Plastic Reconstructive and Aesthetic Surgery. National education standards of specialist doctors in reconstructive and aesthetic plastic surgery in Indonesia. 2018. Jakarta: Indonesian Reconstruction and Aesthetic Plastic Surgery College.

16. Atmodiwirjo P, Ramadan MR, Triatmoko S. Proposal Pelayanan Unggulan Transplantasi Jaringan (Reconstructive Microsurgery). 2019. Presentation.

17. Atmodiwirjo P, Aulia I. How to harvest ALT free flap: step-by-step. 2020. LSBP Press: Jakarta. 